\title{
ANALISIS TINGKAT KUALITAS PELAYANAN JASA TV KABEL DAN INTERNET PADA PT. MALANG MULTIMEDIA MANDIRI
}

\author{
Roni Angger Aditama ${ }^{1}$ \\ ${ }^{1}$ Program Studi Manajemen, STIE Indocakti, J1. R.Panji Suroso 91A, Malang, Indonesia \\ E-mail : roniaditama@gmail.com
}

\begin{abstract}
In this globalization era, the development of information technologcy and communication have raised too, and become an important need by the society. It was becoming a trigger of high competition between cable television and internet service providers. Several ways are done for improving the service quality toward customers. The dimension of services quality are such as tangibles factor, reliability factor, responsiveness factor, assurance factor, and empathy factor. To measure the level of service quality, this research was done in PT. Malang Multimedia Mandiri by taking 100 respondents. Questionnaire was used to collect data and analyzed by descriptive quantitative method. The result of validation test state that the whole attributes are valid by $r$ count $>r$ table that is more than 0.195. By using reliability test stated that the result was reliable with the score of cronbach's alpha $>0.60$. Then,continue with frequency distribution analysis by using IBM SPSS Software version 25 and the result shows that the service quality are good.
\end{abstract}

Keywords: Service Quality; Tangibles; Reliability; Responsiveness; Assurance; Empathy

\section{PENDAHULUAN}

Perkembangan teknologi, informasi, dan komunikasi yang semakin tinggi, khususnya di era globalisasi saat ini menjadi satu peluang besar bagi para provider penyedia layanan TV Kabel dan Internet untuk dapat memberikan pelayanan terbaik kepada pelanggannya, yaitu dengan menghadirkannya beragam informasi digital melalui media TV Kabel dan akses jaringan Internet dengan tujuan untuk memenuhi kebutuhan rutinitas bagi para pelanggan baik itu untuk kebutuhan sekolah, kuliah, pekerjaan dan lain sebagainya.

PT. Malang Multimedia Mandiri atau yang lebih dikenal dengan brand FAZ Media, adalah salah satu dari sekian banyak provider TV Kabel dan Internet di Kota Malang. Merupakan anak cabang dari 15 cabang yang dimiliki oleh PT. Mitra Kabel Indonesia dan saat ini berkantor di Jalan Simpang Sulfat Utara No. 8B dalam kiprahnya sudah berdiri sejak tahun 2013. Dalam kurun waktu hampir 6 (enam) tahun PT. Malang Multimedia Mandiri kini sudah melayani lebih dari 2500 pelanggan yang tersebar di 4 (empat) kecamatan di Kota Malang, yaitu Blimbing, Lowokwaru, Klojen, dan Kedung Kandang.

Di tengah maraknya kebutuhan pelanggan tersebut, hal ini tentu akan memicu tingginya persaingan antar provider penyedia layanan TV Kabel dan Internet khususnya di Kota Malang dengan hampir kurang lebih 7 (tujuh) pelaku bisnis penyedia layanan TV Kabel dan Internet seperti contohnya Indihome, Transvision, MNC Play, My Republik, Biznet, First Media, dan FAZ Media. Sudah pasti tidak dapat dipungkiri lagi dengan semakin banyaknya penyedia layanan TV Kabel dan Internet, pelanggan akan semakin selektif dan memiliki banyak pilihan.

Kemampuan sebuah organisasi bisnis agar dapat bersaing dalam bisnis adalah kemampuan untuk memenangkan pelanggan dari kompetisi. Pelanggan adalah dasar dari bisnis dan asset yang sangat berharga buat perusahaan (Drucker.,1974). Kompetisi saat ini bersifat lebih global dan lebih intens. Banyak perusahaan telah menyadari bahwa mereka 
tidak dapat bersaing pada sisi harga saja, tetapi bersaing pada semua aspek agar pelanggan puas. Artinya perusahaan harus mengembangkan strategi dalam memberikan layanan pelanggan yang unggul untuk membedakan produk dan layanannya dari kompetitor. Survei menunjukkan bahwa perusahaan yang berorientasi pada jasa dapat memanfaatkan keunggulan SDM dalam meningkatkan pelayanan kepada pelanggan.

Berkaitan dengan hal tersebut di atas, maka untuk dapat memenangkan persaingan yang begitu ketat, para provider TV Kabel dan Internet berlomba-lomba untuk berusaha meningkatkan kualitas pelayanannya kepada pelanggan termasuk hal itulah yang dilakukan saat ini oleh PT. Malang Multimedia Mandiri kepada pelanggannya. Sehingga dengan memberikan pelayanan terbaik harapannya pelanggan akan menjadi puas dan akhirnya tetap menjadi pelanggan setia.

Kualitas layanan adalah dilihat sejauh mana pelayanan memenuhi kebutuhan dan harapan pelanggan. Kualitas layanan, seperti apa yang dirasakan pelanggan menimbulkan perbandingan bahwa layanan yang mereka rasakan (harapan pelanggan), dengan penilaian pelanggan terhadap layanan yang diterima (persepsi pelanggan). Jika harapan pelanggan lebih besar dari pada kinerja layanan, maka kualitas yang dirasakan kurang memuaskan dan karenanya terjadi ketidakpuasan pelanggan (Sahney et al., 2006; Al Tamimi et al., 2003).

Adapun kualitas layanan, terdiri atas 5 (lima) dimensi pelayanan: (1) Reliability, Kemampuan untuk melakukan layanan yang dijanjikan dan akurat (2) Tangibles, penampilan fasilitas fisik, peralatan, personil dan materi komunikasi. (3) Responsiveness, kemauan untuk membantu pelanggan dan memberikan layanan yang cepat. (4) Assurance, pengetahuan, kesopanan karyawan, dan kemampuan mereka untuk menyampaikan keyakinan dan kepercayaan. (5) Empathy, dimensi ini mengacu pada tingkat kepedulian perusahaan kepada pelanggan (Parasuraman, Zeithaml, dan Berry., 1988; Al-Tamimi et,al., 2003).

\section{TINJAUAN PUSTAKA}

\subsection{Kualitas Jasa}

Jasa adalah setiap tindakan atau perbuatan yang dapat ditawarkan oleh suatu pihak kepada pihak lainnya yang pada dasarnya bersifat intangible (tidak beruwujud fisik) dan tidak menghasilkan kepemilikan sesuatu (Kotler \& Keller,2012). Kualitas didefinisikan sebagai kondisi dinamis yang berhubungan dengan produk, jasa, sumberdaya manusia, proses, dan lingkungan yang memenuhi atau melebihi harapan pelanggan (Goetsch \& Davis, 2010). Kualitas jasa didefinisikan sebagai ukuran seberapa bagus tingkat layanan yang mampu diberikan sesuai dengan ekspektasi pelanggan (Lewis \& Booms,1983). Berdasarkan definisi ini, kualitas jasa bisa diwujudkan melalui pemenuhan kebutuhan dan keinginan pelanggan serta ketepatan penyampaiannya untuk mengimbangi harapan pelanggan. Dengan demikian, ada dua faktor utama yang mempengaruhi kualitas jasa, yaitu jasa yang diharapkan (expected service) dan jasa yang dirasakan/dipersepsikan (perceived service) (Parasuraman, et al.,1985). Apabila perceived service sesuai dengan expected service, maka kualitas jasa yang bersangkutan akan dipersepsikan baik atau positif. Jika perceived service melebihi expected service, maka kualitas jasa dipersepsikan sebagai kualitas ideal. Sebaliknya, apabila perceived service lebih jelek dibandingkan expected service, maka kualitas jasa dipersepsikan negatif atau buruk. Oleh sebab itu, baik tidaknya kualitas jasa tergantung pada kemampuan penyedia jasa dalam memenuhi harapan pelanggannya secara konsisten.

\subsection{Pelayanan Prima}

Bertitik tolak pada upaya pelaku bisnis untuk memberikan layanan terbaiknya sebagai wujud kepedulian perusahaan kepada pelanggan/konsumen. Maka, diperlukan sebuah pelayanan prima (service excellence) adalah suatu pelayanan terbaik dalam memenuhi harapan dan kebutuhan pelanggan. Dengan kata lain, pelayanan prima merupakan suatu pelayanan yang memenuhi standar kualitas yang sudah ditentukan (Rangkuti 2017:49). 
Tujuan pelayanan prima (service excellence) adalah memberikan pelayanan yang dapat memenuhi dan memuaskan pelanggan sesuai dengan kebutuhan pelanggan dalam rangka:

a) Memposisikan pelanggan/konsumen sebagai seorang raja (customer is king) yang harus memperoleh pelayanan terbaik.

b) Membangun dan menumbuhkan kembali kepercayaan pelanggan/konsumen.

c) Menciptakan pelanggan/konsumen loyal kepada perusahaan.

Adapun prinsip-prinsip pelayanan prima (service excellence) yang berkaitan dengan Attitude (sikap) yang benar, memberikan Attention (perhatian) yang penuh, dengan Action (tindakan) yang cepat dan tepat (Rangkuti 2017:290). Pelayanan berdasarkan konsep Attitude (sikap) meliputi 3 (tiga) prinsip berikut:

1) Melayani pelanggan dengan penampilan (performance) yang sopan dan serasi dalam hal penampilan fisik.

2) Melayani pelanggan dengan positif (positive thinking) dan logis.

3) Melayani pelanggan dengan sikap menghargai.

Pelayanan berdasarkan konsep Attention (perhatian) meliputi 3 (tiga) prinsip berikut:

1) Mendengarkan dan memahami secara sungguh-sungguh kebutuhan pelanggan.

2) Selalu dapat mengamati dan menghargai perilaku pelanggan.

3) Mencurahkan perhatian penuh kepada pelanggan.

Pelayanan berdasarkan konsep Action (tindakan) meliputi 5 (lima) prinsip berikut:

1) Selalu mencatat setiap pesan yang diinginkan dan dikeluhkan oleh pelanggan.

2) Selalu mendata dan mencatat kebutuhan pelanggan.

3) Dapat menegaskan dan menyimpulkan kebutuhan pelanggan.

4) Dapat mewujudkan kebutuhan pelanggan.

5) Adanya terima kasih kepada pelanggan.

Lima area kompetensi yang harus dimiliki oleh setiap karyawan agar dapat memberikan pelayanan berkualitas (Rangkuti 2017:15) antara lain:

1) Service standard

Setiap karyawan selalu berhubungan dengan pelanggan, baik karyawan back office maupun front office. Mereka harus memahami standar mengenai pelayanan yang dibuat oleh perusahaan.

2) Technical skill

Masing-masing unit kerja harus memahami SOP serta sistem yang digunakan dalam bekerja. Memahami tujuan setiap pekerjaan dan mengetahui aliran data, form, serta prosedur.

3) Interpersonal skill

Setiap karyawan wajib memiliki pengetahuan cara berkomunikasi yang baik, cara mendengarkan dan memberikan solusi kepada pelanggan yang membutuhkan, dan selalu berlatih untuk meningkatkan kemampuan berkomunikasi.

4) Keahlian di bidang pelayanan

Setiap karyawan harus mengetahui berbagai faktor teknis yang harus dipersiapkan dalam mencari solusi atau menjawab pertanyaan-pertanyaan yang sering diajukan oleh pelanggan. Serta mengetahui pihak-pihak mana saja yang paling bertanggungjawab untuk membantu memecahkan masalah pelanggan tersebut.

5) Pengetahuan mengenai pelanggan

Pada umumnya tidak semua karyawan mengetahui karakteristik pelanggan, padahal pengetahuan mengenai karakteristik pelanggan merupakan asset perusahaan.

\subsection{Dimensi Kualitas Layanan}

Kualitas layanan terdiri atas 5 (lima) dimensi (Parasuraman, Zeithaml, dan Berry, 1988) antara lain: 
1) Tangibles (Bukti fisik), berkenaan dengan daya tarik fasilitas fisik, perlengkapan, dan material yang digunakan perusahaan, serta penampilan karyawan.

2) Reliability (Reliabilitas), berkaitan dengan kemampuan perusahaan untuk memberikan layanan yang akurat sejak pertama kali tanpa membuat kesalahan apapun dan menyampaikan jasanya sesuai dengan waktu yang disepakati.

3) Responsiveness (Daya tanggap), berkenaan dengan kesediaan dan kemampuan para karyawan untuk membantu para pelanggan dan merespon permintaan mereka, serta menginformasikan kapan jasa akan diberikan dan kemudian memberikan jasa secara cepat.

4) Assurance (Jaminan), yakni perilaku para karyawan mampu menumbuhkan kepercayaan pelanggan terhadap perusahaan dan perusahaan bisa menciptakan rasa aman bagi pelanggannya. Jaminan juga berarti bahwa karyawan selalu bersikap sopan dan menguasai pengetahuan dan keterampilan yang dibutuhkan untuk menangani setiap pertanyaan atau masalah pelanggan.

5) Empathy (Empati), berarti perusahaan memahami masalah para pelanggannya dan bertindak demi kepentingan pelanggan, serta memberikan perhatian personal kepada para pelanggan dan memiliki jam operasi yang fleksibel.

Bahwa di dalam upaya memberikan pelayanan berkualitas terdapat GAP antara perceived service dengan expected service terdapat di dalam Model Konseptual SERVQUAL (Zeithaml, et al., 1990).

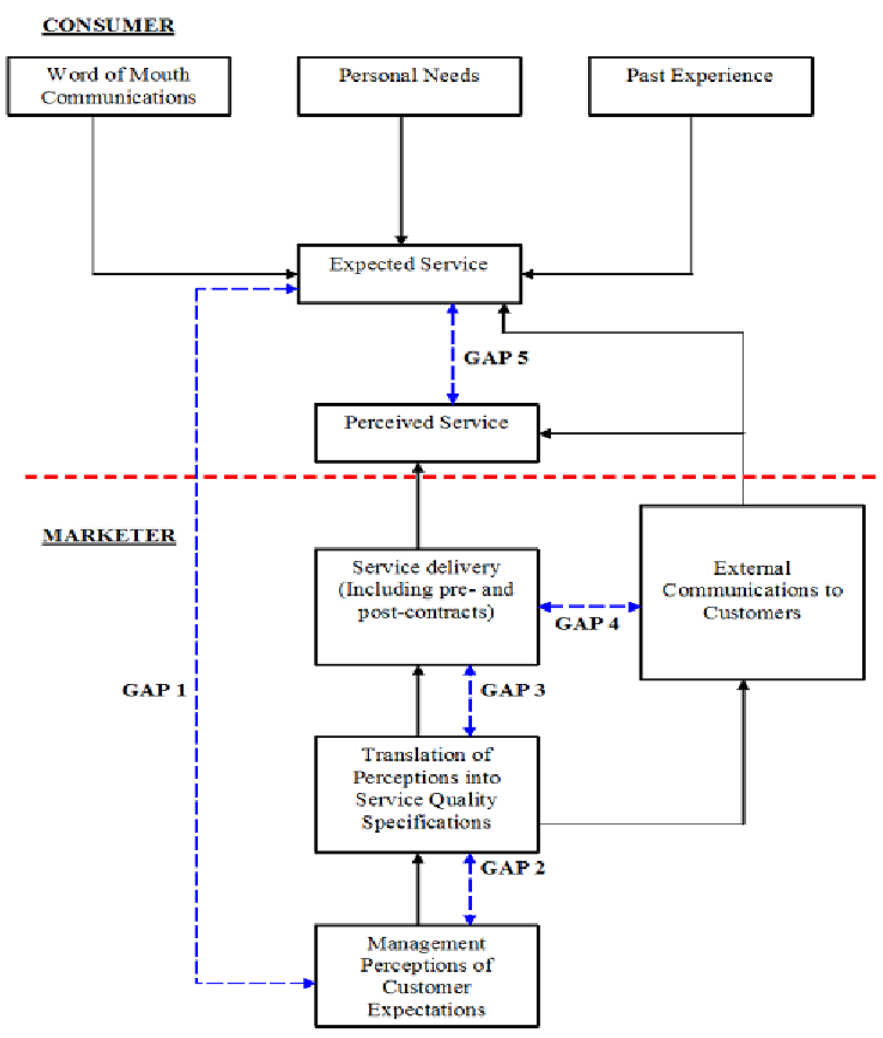

Gambar 1. Model Konseptual SERVQUAL

Sumber: Ziethaml, et al., 1990. meliputi:

5 (lima) GAP yang terangkum di dalam gambar Model Konseptual SERVQUAL

1) GAP Antara Harapan Pelanggan dan Persepsi Manajemen (Knowledge GAP).

Gap ini berarti bahwa pihak manajemen mempersepsikan ekspektasi pelanggan terhadap kualitas jasa secara tidak akurat. Beberapa kemungkinan penyebabnya antara lain: 
informasi yang di dapat dari riset pasar dan analisis permintaan kurang akurat; interpretasi yang kurang akurat atas ekspektasi pelanggan; tidak adanya analisis permintaan; buruknya atau tiadanya aliran informasi ke atas (upward information) dari staf/karyawan ke pihak manajemen; dan terlalu banyak jenjang manajerial yang menghambat atau mengubah informasi yang disampaikan dari staf/karyawan ke pihak manajemen.

2) GAP Antara Persepsi Manajemen terhadap Harapan Konsumen dan Spesifikasi Kualitas Jasa (Standard GAP).

Gap ini berarti bahwa spesifikasi kualitas jasa tidak konsisten dengan persepsi manajemen terhadap ekspektasi kualitas. Penyebabnya antara lain: tidak adanya standar kinerja yang jelas; kesalahan perencanaan atau prosedur perencanaan yang tidak memadai; manajemen perencanaan yang buruk; kurangnya penetapan tujuan yang jelas dalam organisasi; kurangnya dukungan dan komitmen manajemen puncak terhadap perencanaan kualitas jasa; kekurangan sumber daya; dan situasi permintaan yang berlebihan.

3) GAP Antara Spesifikasi Kualitas Jasa dan Penyampaian Jasa (Delivery GAP).

Gap ini berarti bahwa spesifikasi kualitas jasa tidak terpenuhi oleh kinerja dalam proses produksi dan penyampaian jasa. Sejumlah penyebabnya antara lain: spesifikasi kualitas terlalu rumit dan/atau terlalu kaku; para karyawan tidak menyepakati spesifikasi tersebut dan karenanya tidak memenuhinya; spesifikasi tidak sejalan dengan budaya korporat yang ada; manajemen operasi jasa yang buruk; kurang memadainya aktivitas internal marketing; serta teknologi dan sistem yang ada tidak memfasilitasi kinerja sesuai dengan spesifikasi. Kurang terlatihnya karyawan, beban kerja terlampau berlebihan, dan standar kinerja tidak dapat dipenuhi karyawan (terlalu tinggi atau tidak realistis) juga bisa menyebabkan terjadinya gap ini. Selain itu, mungkin pula karyawan dihadapkan pada standar-standar yang kadangkala saling bertentangan satu sama lain.

4) GAP Antara Penyampaian Jasa dan Komunikasi Eksternal (Communications GAP).

Gap ini berarti bahwa janji-janji yang disampaikan melalui aktivitas komunikasi pemasaran tidak konsisten dengan jasa yang disampaikan kepada para pelanggan. Hal ini bisa disebabkan oleh beberapa faktor, diantaranya: perencanaan komunikasi pemasaran tidak terintegrasi dengan operasi jasa; organisasi gagal memenuhi spesifikasi yang ditetapkannya, sementara kampanye komunikasi pemasaran sesuai dengan spesifikasi tersebut; dan kecenderungan untuk melakukan "over-promise, under-deliver". Iklan dan slogan/janji perusahaan seringkali mempengaruhi ekspektasi pelanggan. Jika penyedia jasa memberikan janji berlebihan, maka resikonya adalah harapan pelanggan bisa membumbung tinggi dan sulit terpenuhi.

5) GAP Antara Jasa yang Dipersepsikan dan Jasa yang Diharapkan (Service GAP).

Gap ini berarti bahwa jasa yang dipersepsikan tidak konsisten dengan jasa yang diharapkan. Gap ini bisa menimbulkan sejumlah konsekwensi negatif, seperti kualitas buruk; komunikasi word of mouth yang negatif; dampak negatif terhadap citra korporat; dan kehilangan pelanggan. Gap ini terjadi apabila pelanggan bisa mengukur kinerja/prestasi perusahaan berdasarkan kriteria yang berbeda, atau pelanggan bisa juga mereka keliru menginterpretasikan daripada kualitas jasa bersangkutan.

Dalam hal penelitian sebelumnya yang juga membahas tentang kualitas layanan, dengan judul penelitian "Analisis Pelayanan Jasa Pengiriman Barang Pada PT. Tiki Jalur Nugraha Ekakurir (JNE) Pontianak" (Ahie,2017). Dimana persamaan dalam penelitian tersebut adalah, sama-sama menganalisis tentang kualitas pelayanan dalam bisnis jasa, dengan mengidentifikasi 5 (lima) dimensi kualitas layanan, antara lain Tangibles, Reliability, Responsiveness, Assurance, Empathy. Perbedaan yang ada adalah dalam penelitian terdahulu, metode penelitian yang digunakan adalah metode deskriptif kualitatif. Sedangkan untuk penelitian saat ini, peneliti mencoba untuk melakukan pendekatan dengan kajian yang 
berbeda, yaitu dengan menggunakan metode penelitian deskriptif kuantitatif, antara lain dengan melakukan serangkaian uji validitas, uji reliabilitas, dan analisis distribusi frekuensi terhadap kuesioner yang sudah disebarkan kepada 100 responden. Dengan tujuan dapat mengetahui persepsi pelanggan terhadap dimensi kualitas pelayanan jasa TV Kabel dan Internet di PT. Malang Multimedia Mandiri. Serta sebagai sarana pembuktikan apakah hasil penelitian yang dilakukan dalam berbagai macam metode penelitian yang berbeda mampu menjelaskan secara konsisten bahwa begitu pentingnya membangun kualitas layanan jasa pelanggan bagi keberlangsungan bisnis di masa mendatang, dengan tetap memperhatikan kualitas layanan jasa yang dirasakan (perceived service) oleh pelanggan terhadap kualitas layanan jasa yang diharapkan (expected service) oleh pelanggan.

\section{METODE PENELITIAN}

\subsection{Jenis dan sumber data}

Jenis Penelitian menggunakan metode penelitian deskriptif kuantitatif, menurut Sugiyono (2018:8) metode penelitian kuantitatif dapat diartikan sebagai metode penelitian yang berlandaskan filsafat positivisme, digunakan untuk meneliti populasi atau sampel tertentu, pengumpulan data menggunakan instrument penelitian, analisis data bersifat kuantitatif/statistik.

Dalam penelitian ini menggunakan sumber data primer dan sumber data sekunder. Sumber data primer adalah sumber data yang langsung memberikan data kepada pengumpul data, yaitu untuk teknik pengumpulan datanya dengan menggunakan cara observasi (pengamatan), interview (wawancara), kuesioner (angket). Dan sumber sekunder merupakan sumber yang tidak langsung memberikan data kepada pengumpul data, misalnya melalui orang lain atau dokumen (Sugiyono, 2018:137). Pada penelitian ini, peneliti menggunakan teknik pengumpulan datanya adalah gabungan dari data primer dan data sekunder, agar bisa mendapatkan bahan kajian yang spesifik dan komprehensif. Instrumen penelitian yang dilakukan oleh peneliti yaitu kuesioner tertutup tentang dimensi kualitas layanan, menggunakan skala likert, dengan ketentuan nilai 1 = Tidak Setuju (TS), 2 = Kurang Setuju (KS), 3 = Cukup (C), 4 = Setuju (S), 5 = Sangat Setuju (SS).

\subsection{Sampel dan teknik pengambilan sampel}

Populasi adalah wilayah generalisasi yang terdiri atas: objek/subjek yang mempunyai kualitas dan karakteristik tertentu yang ditetapkan oleh peneliti untuk dipelajari dan kemudian ditarik kesimpulan (Sugiyono, 2018:80). Populasi dalam penelitian ini adalah pelanggan TV kabel dan internet pada PT. Malang Multimedia Mandiri berjumlah 2500 pelanggan.

Sampel adalah bagian dari jumlah dan karakteristik yang dimiliki oleh populasi tersebut. Untuk itu sampel yang diambil dari populasi tersebut, harus betul-betul representative (mewakili) (Sugiyono, 2018:81). Penelitian ini mengambil sampel dengan menggunakan perhitungan rumus Slovin yaitu:

$$
\mathrm{n}=\frac{\mathrm{N}}{\left(1+\mathrm{Ne}^{2}\right)}
$$

dimana: $\mathrm{n}$ adalah ukuran sampel; $\mathrm{N}$ adalah ukuran populasi; $\varepsilon$ adalah presentasi kelonggaran atas kesalahan pengambilan sampel yang ditoleransi $10 \%$ atau 0.1 . Maka berdasarkan rumus Slovin di atas dapat diketahui jumlah sampel yang bisa diambil dalam penelitian ini sebagai berikut:

$$
\begin{aligned}
& \mathrm{n}=\frac{2500}{\left(1+2500 \times 0.1^{2}\right)} \\
& \mathrm{n}=\frac{2500}{26} \\
& \mathrm{n}=96,153=100 \text { pelanggan (pembulatan } 100 \text { pelanggan) }
\end{aligned}
$$




\section{3. $\quad$ Metode Analisis}

Data yang diperoleh melalui kuesioner sejumlah 100 responden dengan 20 atribut pertanyaan yang terdiri dari 5 dimensi kualitas layanan, yang sudah dilakukan uji validitas dan reliabilitas, selanjutnya akan di analisis dengan metode analisis deskriptif kuantitatif persebaran frekuensi. Dalam proses analisis data peneliti menggunakan bantuan program software IBM SPSS versi 25.

\section{Uji Validitas dan Reliabilitas}

Kuesioner dianggap valid apabila dapat digunakan untuk mengukur apa yang seharusnya diukur. Hasil penelitian yang valid bila terdapat kesamaan antara data yang terkumpul dengan data yang sesungguhnya terjadi pada objek yang diteliti (Sugiyono, 2018:121). Pada penelitian ini, terdapat 20 atribut pertanyaan yang terdiri dari 5 dimensi kualitas layanan berdasarkan hasil survey yang dilakukan kepada pelanggan PT. Malang Multimedia Mandiri di tahun 2019.

Dengan uji coba instrument kuesioner 20 atribut pertanyaan kepada 100 orang responden, dengan ketentuan hasil uji validitas dikatakan valid apabila $r$ hitung $\geq \mathrm{r}$ tabel. Dimana $r$ tabel untuk 100 orang responden adalah 0,195. Selanjutnya instrument yang reliabel adalah instrument yang bila digunakan beberapa kali untuk mengukur objek yang sama, akan menghasilkan data yang sama (Sugiyono, 2018:121). Uji reliabilitas ini menggunakan Croncbach Alpha dengan koefisien $\geq 0.6$. Dalam hal ini peneliti melakukan uji validitas dan reliabilitas menggunakan program software IBM SPSS versi 25.

\section{HASIL ANALISIS DAN PEMBAHASAN}

\subsection{Hasil Analisis}

Hasil Uji Validitas

Tabel 1. Hasil Uji Validitas

\begin{tabular}{llccc}
\hline \multicolumn{1}{c}{ Dimensi } & Indikator & r hitung & r tabel & Keterangan \\
\hline Tangibles & T1 & 0.811 & 0.195 & Valid \\
& T2 & 0.895 & 0.195 & Valid \\
& T3 & 0.859 & 0.195 & Valid \\
Reliability & T4 & 0.875 & 0.195 & Valid \\
& T5 & 0.799 & 0.195 & Valid \\
& R1 & 0.939 & 0.195 & Valid \\
& R2 & 0.928 & 0.195 & Valid \\
& R3 & 0.928 & 0.195 & Valid \\
Responsiveness & R4 & 0.790 & 0.195 & Valid \\
& R5 & 0.944 & 0.195 & Valid \\
& Rs1 & 0.901 & 0.195 & Valid \\
Assurance & Rs2 & 0.935 & 0.195 & Valid \\
& Rs3 & 0.862 & 0.195 & Valid \\
& A1 & 0.949 & 0.195 & Valid \\
& A2 & 0.949 & 0.195 & Valid \\
Empathy & A3 & 0.929 & 0.195 & Valid \\
& A4 & 0.937 & 0.195 & Valid \\
& E1 & 0.967 & 0.195 & Valid \\
& E2 & 0.970 & 0.195 & Valid \\
& E3 & 0.918 & 0.195 & Valid \\
\hline
\end{tabular}

Sumber: data diolah IBM SPSS versi 25 
Hasil Uji Reliabilitas

Tabel 2. Hasil Uji Reliabilitas

\begin{tabular}{llll}
\multicolumn{1}{c}{ Dimensi } & & Cronbach's Alpha & Keterangan \\
\hline Tangibles & 0.962 & Reliabel \\
Reliability & 0.957 & Reliabel \\
Responsiveness & 0.951 & Reliabel \\
Assurance & 0.952 & Reliabel \\
Empathy & 0.952 & Reliabel \\
\hline
\end{tabular}

Sumber: data diolah IBM SPSS versi 25

\section{Hasil Uji Distribusi Frekuensi}

Berdasarkan penelitian yang telah dilakukan dengan cara pengisian kuesioner dengan 20 atribut pertanyaan tentang 5 (lima) dimensi kualitas layanan yaitu, tangibles, reliability, responsiveness, assurance, dan empathy kepada 100 responden pada PT. Malang Multimedia Mandiri, maka diperoleh hasil penelitian dengan Uji Distribusi Frekuensi sebagai berikut:

a) Tangibles

1. Persepsi pelanggan terhadap tersedianya jumlah 125 channel TV Digital.

Tabel 3. Persepsi pelanggan terhadap tersedianya jumlah 125 channel TV Digital.

\begin{tabular}{lcc}
\hline \multicolumn{1}{c}{ Persepsi } & Frekuensi & Prosentase \% \\
\hline Tidak Setuju & 0 & $0 \%$ \\
Kurang Setuju & 7 & $7 \%$ \\
Cukup & 16 & $16 \%$ \\
Setuju & 18 & $18 \%$ \\
Sangat Setuju & 59 & $59 \%$ \\
\hline
\end{tabular}

Sumber: data diolah IBM SPSS versi 25

2. Persepsi pelanggan terhadap konten siaran channel TV yang sesuai dengan kebutuhan pelanggan.

Tabel 4.Persepsi pelanggan terhadap konten siaran channel TV yang sesuai dengan kebutuhan pelanggan.

\begin{tabular}{lcc}
\hline \multicolumn{1}{c}{ Persepsi } & Frekuensi & Prosentase \% \\
\hline Tidak Setuju & 0 & $0 \%$ \\
Kurang Setuju & 6 & $6 \%$ \\
Cukup & 20 & $20 \%$ \\
Setuju & 22 & $22 \%$ \\
Sangat Setuju & 52 & $52 \%$ \\
\hline
\end{tabular}

Sumber: data diolah IBM SPSS versi 25 
3. Persepsi pelanggan terhadap kualitas digital dan high definition gambar TV.

Tabel 5. Persepsi pelanggan terhadap kualitas digital dan high definition gambar TV.

\begin{tabular}{lcc}
\multicolumn{1}{c}{ Persepsi } & Frekuensi & Prosentase \\
\hline Tidak Setuju & 0 & $0 \%$ \\
Kurang Setuju & 7 & $7 \%$ \\
Cukup & 19 & $19 \%$ \\
Setuju & 22 & $22 \%$ \\
Sangat Setuju & 52 & $52 \%$
\end{tabular}

Sumber: data diolah IBM SPSS versi 25

4. Persepsi pelanggan terhadap kondisi jaringan atau koneksi kestabilan internet.

Tabel 6. Persepsi pelanggan terhadap kondisi jaringan atau koneksi kestabilan internet

\begin{tabular}{|c|c|c|}
\hline Persepsi & Frekuensi & Prosentase \% \\
\hline Tidak Setuju & 0 & $0 \%$ \\
\hline Kurang Setuju & 15 & $15 \%$ \\
\hline Cukup & 45 & $45 \%$ \\
\hline Setuju & 12 & $12 \%$ \\
\hline Sangat Setuju & 28 & $28 \%$ \\
\hline
\end{tabular}

Sumber: data diolah IBM SPSS versi 25

5. Persepsi pelanggan terhadap kecepatan data internet sesuai paket yang dipilih pelanggan.

Tabel 7. Persepsi pelanggan terhadap kecepatan data internet sesuai paket yang dipilih pelanggan

\begin{tabular}{lcc}
\hline \multicolumn{1}{c}{ Persepsi } & Frekuensi & Prosentase \% \\
\hline Tidak Setuju & 0 & $0 \%$ \\
Kurang Setuju & 18 & $18 \%$ \\
Cukup & 44 & $44 \%$ \\
Setuju & 12 & $12 \%$ \\
Sangat Setuju & 26 & $26 \%$ \\
\hline
\end{tabular}

Sumber: data diolah IBM SPSS versi 25

\section{b) Reliability}

1. Persepsi pelanggan terhadap adanya kepastian informasi kapan waktu perbaikan komplain.

Tabel 8. Persepsi pelanggan terhadap adanya kepastian informasi kapan waktu perbaikan komplain

\begin{tabular}{lcc}
\multicolumn{1}{c}{ Persepsi } & Frekuensi & Prosentase \% \\
\hline Tidak Setuju & 0 & $0 \%$ \\
Kurang Setuju & 6 & $6 \%$ \\
Cukup & 22 & $22 \%$ \\
Setuju & 27 & $27 \%$ \\
Sangat Setuju & 45 & $45 \%$ \\
\hline
\end{tabular}

Sumber: data diolah IBM SPSS versi 25 
2. Persepsi pelanggan terhadap ketepatan waktu tim teknik menghandle komplain.

Tabel 9. Persepsi pelanggan terhadap ketepatan waktu tim teknik menghandle komplain

\begin{tabular}{lcc}
\hline \multicolumn{1}{c}{ Persepsi } & Frekuensi & Prosentase \% \\
\hline Tidak Setuju & 0 & $0 \%$ \\
Kurang Setuju & 6 & $6 \%$ \\
Cukup & 18 & $18 \%$ \\
Setuju & 35 & $35 \%$ \\
Sangat Setuju & 41 & $41 \%$ \\
\hline
\end{tabular}

Sumber: data diolah IBM SPSS versi 25

3. Persepsi pelanggan terhadap kemampuan tim teknik mampu menyelesaikan keluhan.

Tabel 10. Persepsi pelanggan terhadap kemampuan tim teknik mampu menyelesaikan keluhan

\begin{tabular}{lcc}
\hline \multicolumn{1}{c}{ Persepsi } & Frekuensi & Prosentase \% \\
\hline Tidak Setuju & 0 & $0 \%$ \\
Kurang Setuju & 2 & $2 \%$ \\
Cukup & 24 & $24 \%$ \\
Setuju & 33 & $33 \%$ \\
Sangat Setuju & 41 & $41 \%$ \\
\hline
\end{tabular}

Sumber: data diolah IBM SPSS versi 25

4. Persepsi pelanggan terhadap ketepatan waktu tim kolektor melakukan penarikan IJT.

Tabel 11. Persepsi pelanggan terhadap ketepatan waktu tim kolektor melakukan penarikan IJT

\begin{tabular}{lcc}
\multicolumn{1}{c}{ Persepsi } & Frekuensi & Prosentase \% \\
\hline Tidak Setuju & 0 & $0 \%$ \\
Kurang Setuju & 3 & $3 \%$ \\
Cukup & 18 & $18 \%$ \\
Setuju & 30 & $30 \%$ \\
Sangat Setuju & 49 & $49 \%$ \\
\hline
\end{tabular}

Sumber: data diolah IBM SPSS versi 25

5. Persepsi pelanggan terhadap kemampuan tim marketing menjelaskan detail program/paket unggulan TV dan Internet.

Tabel 12. Persepsi pelanggan terhadap kemampuan tim marketing menjelaskan detail program/paket unggulan TV dan Internet

\begin{tabular}{lcc}
\hline \multicolumn{1}{c}{ Persepsi } & Frekuensi & Prosentase \% \\
\hline Tidak Setuju & 0 & $0 \%$ \\
Kurang Setuju & 0 & $0 \%$ \\
Cukup & 24 & $24 \%$ \\
Setuju & 33 & $33 \%$ \\
Sangat Setuju & 43 & $43 \%$ \\
\hline
\end{tabular}

Sumber: data diolah IBM SPSS versi 25 
The Studies of Social Science

Volume 1, Number 1, 2019

pp. 34-50

c) Responsiveness

1. Persepsi pelanggan terhadap customer service cepat tanggap melayani keluhan pelanggan baik di kantor maupun melalui telepon.

Tabel 13. Persepsi pelanggan terhadap customer service cepat tanggap melayani keluhan pelanggan baik di kantor maupun melalui telepon

\begin{tabular}{llll}
\hline \multicolumn{1}{c}{ Persepsi } & Frekuensi & & Prosentase \% \\
\hline Tidak Setuju & 0 & $0 \%$ & \\
Kurang Setuju & 2 & $2 \%$ & \\
Cukup & 24 & $31 \%$ & \\
Setuju & 31 & $43 \%$ & \\
Sangat Setuju & 43 & &
\end{tabular}

Sumber: data diolah IBM SPSS versi 25

2. Persepsi pelanggan terhadap tim teknik yang cepat tanggap menyelesaikan keluhan dan proses pemasangan instalasi dalam kurun waktu 1x24 jam.

Tabel 14. Persepsi pelanggan terhadap tim teknik yang cepat tanggap menyelesaikan keluhan dan proses pemasangan instalasi dalam kurun waktu 1x24 jam.

\begin{tabular}{lcc}
\hline \multicolumn{1}{c}{ Persepsi } & Frekuensi & Prosentase \% \\
\hline Tidak Setuju & 0 & $0 \%$ \\
Kurang Setuju & 6 & $6 \%$ \\
Cukup & 19 & $19 \%$ \\
Setuju & 31 & $31 \%$ \\
Sangat Setuju & 44 & $44 \%$ \\
\hline
\end{tabular}

Sumber: data diolah IBM SPSS versi 25

3. Persepsi pelanggan terhadap tim kolektor yang cepat tanggap melayani permintaan pelanggan terkait IJT.

Tabel 15. Persepsi pelanggan terhadap tim kolektor yang cepat tanggap melayani permintaan pelanggan terkait IJT

\begin{tabular}{lcc}
\hline \multicolumn{1}{c}{ Persepsi } & Frekuensi & Prosentase \% \\
\hline Tidak Setuju & 0 & $0 \%$ \\
Kurang Setuju & 0 & $0 \%$ \\
Cukup & 22 & $22 \%$ \\
Setuju & 33 & $33 \%$ \\
Sangat Setuju & 45 & $45 \%$ \\
\hline
\end{tabular}

Sumber: data diolah IBM SPSS versi 25

d) Assurance

1. Persepsi pelanggan terhadap customer service yang menerapkan 5S (senyum, salam, sapa, sopan, santun). 
Tabel 16. Persepsi pelanggan terhadap customer service yang menerapkan 5S (senyum, salam, sapa, sopan, santun)

\begin{tabular}{lcc}
\hline \multicolumn{1}{c}{ Persepsi } & Frekuensi & Prosentase \% \\
\hline Tidak Setuju & 0 & $0 \%$ \\
Kurang Setuju & 0 & $0 \%$ \\
Cukup & 22 & $22 \%$ \\
Setuju & 34 & $34 \%$ \\
Sangat Setuju & 44 & $44 \%$ \\
\hline
\end{tabular}

Sumber: data diolah IBM SPSS versi 25

2. Persepsi pelanggan terhadap tim teknik saat menangani keluhan dengan sikap yang sopan santun.

Tabel 17. Persepsi pelanggan terhadap tim teknik saat menangani keluhan dengan sikap yang sopan santun

\begin{tabular}{lcc}
\hline \multicolumn{1}{c}{ Persepsi } & Frekuensi & Prosentase \% \\
\hline Tidak Setuju & 0 & $0 \%$ \\
Kurang Setuju & 0 & $0 \%$ \\
Cukup & 26 & $22 \%$ \\
Setuju & 30 & $34 \%$ \\
Sangat Setuju & 44 & $44 \%$ \\
\hline
\end{tabular}

Sumber: data diolah IBM SPSS versi 25

3. Persepsi pelanggan terhadap tim kolektor yang ramah tamah saat proses penagihan IJT.

Tabel 18. Persepsi pelanggan terhadap tim kolektor yang ramah tamah saat proses penagihan IJT

\begin{tabular}{lcc}
\multicolumn{1}{c}{ Persepsi } & Frekuensi & Prosentase \% \\
\hline Tidak Setuju & 0 & $0 \%$ \\
Kurang Setuju & 0 & $0 \%$ \\
Cukup & 20 & $20 \%$ \\
Setuju & 31 & $31 \%$ \\
Sangat Setuju & 49 & $49 \%$ \\
\hline
\end{tabular}

Sumber: data diolah IBM SPSS versi 25.

4. Persepsi pelanggan terhadap tim marketing yang menjalin hubungan dan komunikasi yang baik dengan pelanggan (after sales service).

Tabel 19. Persepsi pelanggan terhadap tim marketing yang menjalin hubungan dan komunikasi yang baik dengan pelanggan (after sales service)

\begin{tabular}{lcc}
\hline \multicolumn{1}{c}{ Persepsi } & Frekuensi & Prosentase \% \\
\hline Tidak Setuju & 0 & $0 \%$ \\
Kurang Setuju & 0 & $0 \%$ \\
Cukup & 21 & $21 \%$ \\
Setuju & 31 & $31 \%$ \\
Sangat Setuju & 48 & $48 \%$ \\
\hline
\end{tabular}

Sumber: data diolah IBM SPSS versi 25 
The Studies of Social Science

Volume 1, Number 1, 2019

pp. 34-50

e) Empathy

1. Persepsi pelanggan terhadap pemberian waktu keleluasaan kepada pelanggan yang menunggak pembayaran dengan komitmen waktu tertentu dan tanpa dikenakan denda.

Tabel 20. Persepsi pelanggan terhadap pemberian waktu keleluasaan kepada pelanggan yang menunggak pembayaran dengan komitmen waktu tertentu dan tanpa dikenakan denda

\begin{tabular}{lcc}
\hline \multicolumn{1}{c}{ Persepsi } & Frekuensi & Prosentase \% \\
\hline Tidak Setuju & 0 & $0 \%$ \\
Kurang Setuju & 2 & $2 \%$ \\
Cukup & 18 & $18 \%$ \\
Setuju & 33 & $33 \%$ \\
Sangat Setuju & 47 & $47 \%$ \\
\hline
\end{tabular}

Sumber: data diolah IBM SPSS versi 25

2. Persepsi pelanggan terhadap tim kolektor tidak melakukan pemaksaan pada saat melakukan penagihan.

Tabel 21. Persepsi pelanggan terhadap tim kolektor tidak melakukan pemaksaan pada saat melakukan penagihan.

\begin{tabular}{lcc}
\hline \multicolumn{1}{c}{ Persepsi } & Frekuensi & Prosentase \% \\
\hline Tidak Setuju & 0 & $0 \%$ \\
Kurang Setuju & 2 & $2 \%$ \\
Cukup & 16 & $16 \%$ \\
Setuju & 35 & $35 \%$ \\
Sangat Setuju & 47 & $47 \%$ \\
\hline
\end{tabular}

Sumber: data diolah IBM SPSS versi 25

3. Persepsi pelanggan terhadap tim teknik melakukan konfirmasi kesediaan waktu terlebih dahulu kepada pelanggan sebelum datang ke rumah.

Tabel 22. Persepsi pelanggan terhadap tim teknik melakukan konfirmasi kesediaan waktu terlebih dahulu kepada pelanggan sebelum datang ke rumah.

\begin{tabular}{lcc}
\hline \multicolumn{1}{c}{ Persepsi } & Frekuensi & Prosentase \% \\
\hline Tidak Setuju & 0 & $0 \%$ \\
Kurang Setuju & 2 & $2 \%$ \\
Cukup & 17 & $17 \%$ \\
Setuju & 33 & $33 \%$ \\
Sangat Setuju & 48 & $48 \%$ \\
\hline
\end{tabular}

Sumber: data diolah IBM SPSS versi 25

\subsection{Pembahasan}

Berdasarkan dari hasil perhitungan pada tabel 1 di atas, menunjukkan bahwa koefisien korelasi atau $\mathrm{r}$ hitung pada 5 (lima) dimensi kualitas layanan dengan 20 atribut pertanyaan hasilnya $r$ hitung $\geq r$ tabel yaitu 0.195 . Dengan nilai koefisien korelasi tertinggi yaitu 0.970 dan koefisien korelasi terendah yaitu 0.790. Artinya bahwa seluruh pertanyaan atau indikator di dalam kuesioner kualitas layanan dinyatakan valid.

Berdasarkan hasil uji realibilitas yang disajikan pada tabel 2 di atas keseluruhan dimensi kualitas layanan memiliki koefisien Cronbach's Alpha $\geq 0.60$. Sehingga hal ini dapat disimpulkan bahwa semua instrumen reliabel dan dapat digunakan untuk melakukan 
penelitian.

Berdasarkan tabel 3 tersebut dapat diketahui, bahwa prosentase terendah adalah kurang setuju dengan $7 \%$ dan prosentase tertinggi adalah sangat setuju 59\%. Dengan demikian dapat disimpulkan bahwa sebagian besar responden memiliki persepsi yang baik terhadap tersedianya jumlah 125 channel TV Digital.

Berdasarkan tabel 4 tersebut dapat diketahui, bahwa prosentase terendah adalah kurang setuju dengan 6\% dan prosentase tertinggi adalah sangat setuju 52\%. Dengan demikian dapat disimpulkan bahwa sebagian besar responden memiliki persepsi yang baik terhadap konten siaran channel TV yang sesuai dengan kebutuhan pelanggan.

Berdasarkan tabel 5 tersebut dapat diketahui, bahwa prosentase terendah adalah kurang setuju dengan 7\% dan prosentase tertinggi adalah sangat setuju 52\%. Dengan demikian dapat disimpulkan bahwa sebagian besar responden memiliki persepsi yang baik terhadap kualitas digital dan high definition gambar TV.

Berdasarkan tabel 6 tersebut dapat diketahui, bahwa prosentase terendah adalah setuju dengan $12 \%$ dan prosentase tertinggi adalah cukup $45 \%$. Akan tetapi memang ada $15 \%$ yang menyatakan kurang setuju. Dengan demikian dapat disimpulkan bahwa sebagian besar responden memiliki persepsi yang cukup baik terhadap kondisi jaringan atau koneksi kestabilan internet.

Berdasarkan tabel 7 tersebut dapat diketahui, bahwa prosentase terendah adalah setuju dengan $12 \%$ dan prosentase tertinggi adalah cukup $44 \%$. Akan tetapi memang ada $18 \%$ yang menyatakan kurang setuju. Dengan demikian dapat disimpulkan bahwa sebagian besar responden memiliki persepsi yang cukup baik terhadap kecepatan data internet sesuai paket yang dipilih pelanggan.

Berdasarkan tabel 8 tersebut dapat diketahui, bahwa prosentase terendah adalah kurang setuju dengan $6 \%$ dan prosentase tertinggi adalah sangat setuju $45 \%$. Dengan demikian dapat disimpulkan bahwa sebagian besar responden memiliki persepsi yang baik terhadap adanya kepastian informasi kapan waktu perbaikan komplain.

Berdasarkan tabel 9 tersebut dapat diketahui, bahwa prosentase terendah adalah kurang setuju dengan 6\% dan prosentase tertinggi adalah sangat setuju $41 \%$. Dengan demikian dapat disimpulkan bahwa sebagian besar responden memiliki persepsi yang baik terhadap ketepatan waktu tim teknik menghandle komplain.

Berdasarkan tabel 10 tersebut dapat diketahui, bahwa prosentase terendah adalah kurang setuju dengan $2 \%$ dan prosentase tertinggi adalah sangat setuju $41 \%$. Dengan demikian dapat disimpulkan bahwa sebagian besar responden memiliki persepsi yang baik terhadap kemampuan tim teknik mampu menyelesaikan keluhan.

Berdasarkan tabel 11 tersebut dapat diketahui, bahwa prosentase terendah adalah kurang setuju dengan 3\% dan prosentase tertinggi adalah sangat setuju 49\%. Dengan demikian dapat disimpulkan bahwa sebagian besar responden memiliki persepsi yang baik terhadap ketepatan waktu tim kolektor melakukan penarikan IJT.

Berdasarkan tabel 12 tersebut dapat diketahui, bahwa prosentase terendah adalah cukup dengan $24 \%$ dan prosentase tertinggi adalah sangat setuju $43 \%$. Dengan demikian dapat disimpulkan bahwa sebagian besar responden memiliki persepsi yang baik terhadap kemampuan tim marketing menjelaskan detail program/paket unggulan TV dan Internet.

Berdasarkan tabel 13 tersebut dapat diketahui, bahwa prosentase terendah adalah kurang setuju dengan $2 \%$ dan prosentase tertinggi adalah sangat setuju $43 \%$. Dengan demikian dapat disimpulkan bahwa sebagian besar responden memiliki persepsi yang baik terhadap customer service cepat tanggap melayani keluhan pelanggan baik di kantor maupun melalui telepon.

Berdasarkan tabel 14 tersebut dapat diketahui, bahwa prosentase terendah adalah kurang setuju dengan $6 \%$ dan prosentase tertinggi adalah sangat setuju $44 \%$. Dengan 
demikian dapat disimpulkan bahwa sebagian besar responden memiliki persepsi yang baik terhadap tim teknik yang cepat tanggap menyelesaikan keluhan dan proses pemasangan instalasi dalam kurun waktu 1x24 jam.

Berdasarkan tabel 15 tersebut dapat diketahui, bahwa prosentase terendah adalah cukup dengan $22 \%$ dan prosentase tertinggi adalah sangat setuju $45 \%$. Dengan demikian dapat disimpulkan bahwa sebagian besar responden memiliki persepsi yang baik terhadap tim kolektor yang cepat tanggap melayani permintaan pelanggan terkait IJT.

Berdasarkan tabel 16 tersebut dapat diketahui, bahwa prosentase terendah adalah cukup dengan $22 \%$ dan prosentase tertinggi adalah sangat setuju $44 \%$. Dengan demikian dapat disimpulkan bahwa sebagian besar responden memiliki persepsi yang baik terhadap customer service yang menerapkan 5S (senyum, salam, sapa, sopan, santun).

Berdasarkan tabel 17 tersebut dapat diketahui, bahwa prosentase terendah adalah cukup dengan $26 \%$ dan prosentase tertinggi adalah sangat setuju $44 \%$. Dengan demikian dapat disimpulkan bahwa sebagian besar responden memiliki persepsi yang baik terhadap tim teknik saat menangani keluhan dengan sikap yang sopan santun.

Berdasarkan tabel 18 tersebut dapat diketahui, bahwa prosentase terendah adalah cukup dengan $20 \%$ dan prosentase tertinggi adalah sangat setuju $49 \%$. Dengan demikian dapat disimpulkan bahwa sebagian besar responden memiliki persepsi yang baik terhadap tim kolektor yang ramah tamah saat proses penagihan IJT.

Berdasarkan tabel 19 tersebut dapat diketahui, bahwa prosentase terendah adalah cukup dengan $21 \%$ dan prosentase tertinggi adalah sangat setuju $48 \%$. Dengan demikian dapat disimpulkan bahwa sebagian besar responden memiliki persepsi yang baik terhadap tim marketing yang menjalin hubungan dan komunikasi yang baik dengan pelanggan (after sales service).

Berdasarkan tabel 20 tersebut dapat diketahui, bahwa prosentase terendah adalah kurang setuju dengan $2 \%$ dan prosentase tertinggi adalah sangat setuju $47 \%$. Dengan demikian dapat disimpulkan bahwa sebagian besar responden memiliki persepsi yang baik terhadap pemberian waktu keleluasaan kepada pelanggan yang menunggak pembayaran dengan komitmen waktu tertentu dan tanpa dikenakan denda.

Berdasarkan tabel 21 tersebut dapat diketahui, bahwa prosentase terendah adalah kurang setuju dengan $2 \%$ dan prosentase tertinggi adalah sangat setuju $47 \%$. Dengan demikian dapat disimpulkan bahwa sebagian besar responden memiliki persepsi yang baik terhadap tim kolektor tidak melakukan pemaksaan pada saat melakukan penagihan.

Berdasarkan tabel 22 tersebut dapat diketahui, bahwa prosentase terendah adalah kurang setuju dengan $2 \%$ dan prosentase tertinggi adalah sangat setuju $48 \%$. Dengan demikian dapat disimpulkan bahwa sebagian besar responden memiliki persepsi yang baik terhadap tim teknik melakukan konfirmasi kesediaan waktu terlebih dahulu kepada pelanggan sebelum datang ke rumah.

\section{KESIMPULAN DAN SARAN}

\subsection{Kesimpulan}

Berdasarkan hasil penelitian yang diuraikan di atas, maka dapat disimpulkan berdasarkan kuesioner yang disebarkan kepada 100 responden dengan 20 atribut pertanyaan mengenai analisis tingkat kualitas layanan jasa TV Kabel dan Internet pada PT. Malang Multimedia Mandiri adalah sebagai berikut:

1. Persepsi pelanggan terhadap dimensi kualitas pelayanan jasa TV Kabel dan Internet pada PT. Malang Multimedia Mandiri berdasarkan aspek Tangibles, dinilai relatif baik sesuai dengan hasil analisis data distribusi frekuensi. Akan tetapi ada 2 (dua) atribut perolehan tertinggi tapi dengan hasil cukup yaitu persepsi pelanggan terhadap kondisi jaringan atau 
koneksi kestabilan internet dan persepsi pelanggan terhadap kecepatan data internet sesuai paket yang dipilih pelanggan.

2. Persepsi pelanggan terhadap dimensi kualitas pelayanan jasa TV Kabel dan Internet PT. Malang Multimedia Mandiri berdasarkan aspek Reliability, dinilai sebagian besar responden baik sesuai dengan hasil analisis data distribusi frekuensi.

3. Persepsi pelanggan terhadap dimensi kualitas pelayanan jasa TV Kabel dan Internet PT. Malang Multimedia Mandiri berdasarkan aspek Responsiveness, dinilai sebagian besar responden baik sesuai dengan hasil analisis data distribusi frekuensi.

4. Persepsi pelanggan terhadap dimensi kualitas pelayanan jasa TV Kabel dan Internet PT. Malang Multimedia Mandiri berdasarkan aspek Assurance, dinilai sebagian besar responden baik sesuai dengan hasil analisis data distribusi frekuensi.

5. Persepsi pelanggan terhadap dimensi kualitas pelayanan jasa TV Kabel dan Internet PT. Malang Multimedia Mandiri berdasarkan aspek Empathy, dinilai sebagian besar responden baik sesuai dengan hasil analisis data distribusi frekuensi.

\subsection{Saran}

Berdasarkan dari hasil kesimpulan di atas, maka peneliti bermaksud menyampaikan beberapa saran antara lain:

1. Sebaiknya ada dibuatkan standar kerja berupa SOP dan IK yang mengatur serta menjelaskan secara detail bagaimana seorang karyawan mampu melayani pelanggan dengan baik.

2. Sebaiknya perusahaan perlu memperhatikan aspek-aspek yang bisa memotivasi para karyawan khususnya yang bekerja sebagai frontline (CS/teknisi/kolektor) agar mereka dalam bekerja lebih semangat dalam memberikan pelayanan terbaik.

3. Sebaiknya perlu diadakan training service excellence kepada seluruh karyawan agar mereka mendapatkan pengetahuan tentang, bagaimana memberikan pelayanan terbaik, memahami cara berkomunikasi, mengerti cara bersikap, serta bisa memahami berbagai macam karakter pelanggan dan bagaimana cara menghadapinya.

\section{DAFTAR PUSTAKA}

Ahie,Simon. (2017). Analisis Pelayanan Jasa Pengiriman Barang Pada PT. Tiki Jalur Nugraha Ekakurir (JNE). Integra. Vol.7 (1):001-014.

Al-Tamimi, H. A. H., \& Al-Amiri, A. (2003). Analysing service quality in the UAE Islamic banks. Journal of Financial Services Marketing, 8(2), 119-132.

Drucker, Peter F. (1974). Management: Tasks, Responsibilities, Practices. Herper \& Row. New York-USA.

Goetsch,D.L and S.B Davis. (2010), Quality Management for Organizational Excellence; Introduction to Total Quality, $6^{\text {th }}$ Ed. N.J:Pearson Education Inc. Upper Saddle River.

Kotler,P, and K.L. Keller. (2012). Marketing Management, $14^{\text {th }}$ Ed. NJ: Pearson Education Inc.Upper Saddle River.

Lewis,R.C and B.H Booms. (1983), "The Marketing Aspect of Service Quality", Chicago:American Marketing Association, pp.99-107.

Parasuraman, A., Zeithaml, V.A. and Berry, L.L. (1988), "SERVQUAL:a multiple-item scale for measuring consumer perceptions of service quality”, Journal of Retailing, Vol. 64 No. 1, pp. 12-40.

Parasuraman, A., Zeithaml, V.A. and Berry, L.L. (1985), “A Conceptual Model of Service Quality and its Implications for Future Research”, Journal Marketing, Vol. 49, Fall,pp. $41-50$ 
The Studies of Social Science

Volume 1, Number 1, 2019

pp. 34-50

Rangkuti, Freddy. (2018). Customer Care Excellence. PT. Gramedia Pustaka Utama. Jakarta.

Sahney, S., Banwet, D. K., \& Karunes, S. (2006). An Integrated Framework for Quality in

Education: Application of Quality Function Deployment, Interpretive Structural Modelling and Path Analysis. Total Quality Management, 17(2), 265-285.

Sugiyono. (2018). Metode Penelitian:Kuantitatif, Kualitatif, dan R\&D. Alfabeta. Bandung Tjiptono, Fandy. (2016). Service, Quality \& Satisfaction, Edisi 4. Andi Offset.Yogyakarta.

Zeithaml,VA, L.LBerry, and A. Parasuraman (1990), Delivering Quality Service. The Free Press. New York-USA. 